\title{
Nutritional and energy value of wheat cultivars for broiler chickens
}

\author{
O. Lasek ${ }^{1,3}$, J. Barteczko $^{1}$, R. Augustyn ${ }^{1}$, S. Smulikowska ${ }^{2}$ \\ and F. Borowiec ${ }^{1}$
}

\author{
${ }^{1}$ Agriculture University of Krakow, Department of Animal Nutrition and Feed Management \\ Al. Mickiewicza 24/28, 30-059 Kraków, Poland \\ ${ }^{2}$ The Kielanowski Institute of Animal Physiology and Nutrition, Polish Academy of Sciences \\ 05-110 Jabtonna, Poland
}

(Received 24 January 2011; revised version 18 May 2011; accepted 18 June 2011)

\begin{abstract}
Wheat (Triticum aestivum L.) grain of 6 spring and 3 winter cultivars was analysed for nutrients content including amino acids, fatty acids, starch, sugars and fibre, and dietary fibrę fractions. Digestibility of main nutrients and amino acids, and apparent metabolizable energy $\left(\mathrm{AME}_{\mathrm{N}}\right)$ were determined in broiler chicken. The experiment was carried out on 45 unsexed Ross 308 broiler chickens ( 9 groups of 5 birds) aged 42 days, maintained in individual balance cages. During 7 days birds were given wheat grain as the only feed and in the last 3 days feed intake was measured and excreta was collected and analysed.

Protein content ranged from 123 to $155 \mathrm{~g} / \mathrm{kg}$ DM, starch content from 614 to $748 \mathrm{~g} / \mathrm{kg} \mathrm{DM}$, ADL fraction from 0.1 to $4.4 \mathrm{~g} / \mathrm{kg} \mathrm{DM}$. Mean digestibility of all nutrients and $\mathrm{AME}_{\mathrm{N}}$ values were lower while nitrogen retention was higher in spring than in winter varieties (mean $\mathrm{AME}_{\mathrm{N}}$ values $12.6 \mathrm{vs}$ 13.1 M J/kg, respectively). Among wheat cultivars significant differences of nutrients digestibility and $\mathrm{AME}_{\mathrm{N}}$ values were found. It is concluded that $\mathrm{AME}_{\mathrm{N}}$ value of wheat was not related to protein or starch contents while it was negatively affected by ADL content.
\end{abstract}

KEY WORDS: wheat cultivars, broiler chickens, digestibility, amino acids, $\mathrm{AME}_{\mathrm{N}}$

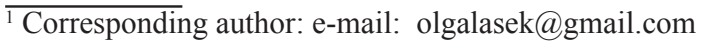




\section{INTRODUCTION}

Wheat (Triticum aestivum L.) grain in Europe is one of the main components of broiler diets, but results obtained with diets containing high proportions of wheat may be unsatisfactory due to varying chemical composition and energy value of the grain (Steenfeldt, 2001; Pirgozliev et al., 2003). The Polish Nutrient Requirements of Poultry (Smulikowska and Rutkowski, 2005) comprise only one set of average values for components of wheat grain, thus assuming slight varietal differences. According to Classen et al. (1995) and Steenfeldt (2001) wheat cultivars can differ in protein, starch and fibre content as well as in nutrient digestibility and the apparent metabolizable energy value $\left(\mathrm{AME}_{\mathrm{N}}\right)$ for poultry. A thorough examination of chemical composition, nutrient digestibility and energy value wheat cultivars grown in Poland may help to increase the efficiency of their use in broiler nutrition, thus bringing tangible economic benefits.

The aim of the study was to determine the nutritive and energy value of different Polish wheat cultivars in broiler chickens.

\section{MATERIAL AND METHODS}

Six cultivars of spring wheat (Vinjett, Napola, Bryza, Zebra, Bombona, Torka) and 3 cultivars of winter wheat (Mikula, Satyna, Muza) were investigated. All wheat cultivars were grown on an experimental farm Małopolska Plant Raising HBP Ltd. near Kraków (Poland) and were harvested in the year 2005.

Chemical composition including amino acids, fatty acids, starch, sugars, crude fibre and dietary fibre fractions, was analysed. Total tract digestibility of main nutrients and amino acids, and apparent metabolizable energy value $\left(\mathrm{AME}_{\mathrm{N}}\right)$ were determined in broiler chicken.

Before digestibility trial broiler chickens were kept in pens and fed standard broiler starter diet from 0 to $14 \mathrm{~d}$ of life, then from 14 to $42 \mathrm{~d}$ of life were kept in individual cages and fed diets based on the evaluated wheat cvs and containing $\left(\mathrm{g} \cdot \mathrm{kg}^{-1}\right)$ : wheat 735.6 , soyabean meal 150 , fish meal 80 , monocalcium phosphate 8, limestone 18, L-lysine 1.2, DL-methionine 2.2, vitamin-mineral premix 5, to satisfy nutrient requirements of broilers according to Smulikowska and Rutkowski (2005). A digestibility trial was performed by standard method using 45 unsexed Ross 308 chickens ( 9 groups with 5 birds per group) aged 42 days. Birds were kept individually in balance cages $(400 \times 600 \mathrm{~mm})$ with constant access to feed and water. Chickens received the coarsely ground grain of the respective wheat cultivars without any additives on an ad libitum basis. The experiment lasted $7 \mathrm{~d}$ including $4 \mathrm{~d}$ of adaptation, and $3 \mathrm{~d}$ of excreta collection. Feed intake was 
measured and excreta from each bird were collected twice a day from trays placed below the cages, pooled and kept frozen at $-18^{\circ} \mathrm{C}$ until analysis.

All procedures were approved by the Local Animal Care and Use Committee.

\section{Chemical analyses}

The content of dry matter, nitrogen, crude fat, crude ash and crude fibre in wheat grain and excreta was determined according to AOAC (2005), while $\alpha$-amino nitrogen in excreta was measured according to Barteczko et al. (1993). The content of gross energy (GE) in wheat grain and excreta was measured using Parr adiabatic oxygen bomb calorimeter (KL-10, Precyzja, Bydgoszcz, Poland). The amino acid composition of wheat grain and excreta was determined by liquid chromatography using an INGOS AAA-400 amino acid analyser (Czech Republic), equipped with column Ostion LG ANB (370 mm), column temperature $55^{\circ} \mathrm{C}$, reactor temperature $120^{\circ} \mathrm{C}$, detection wavelengths 440 and $570 \mathrm{~mm}$. In wheat grain the content of neutral detergent fibre (NDF), acid detergent fibre (ADF) and acid detergent lignin (ADL) were determined using an $\mathrm{ANKOM}^{220}$ Fiber Analyser (Ankom Products, NY, USA) according to Goering and Van Soest (1970), whereas soluble (SDF) and insoluble (IDF) dietary fibre were analysed by an enzymatic method according to Englyst and Cummings (1988). Starch content in wheat grain was determined by an enzymatic method according to Faisant et al. (1995), whereas amylose and amylopectin in starch by the method of Morrison and Laignelet (1983). Total sugars were determined by a spectrofotometric method according to Zagrodzki et al. (1969), using colour reaction with anthron mixed with pure concentrated $\mathrm{H}_{2} \mathrm{SO}_{4}$. Before measurement samples was deproteinized using a solution of $\mathrm{Zn}(\mathrm{CHCOO})_{2} \cdot \mathrm{H}_{2} \mathrm{O} 275.12 \mathrm{~g} / 1$ and $\mathrm{K}_{4} \mathrm{Fe}\left(\mathrm{CN}_{6}\right) \cdot 3 \mathrm{H}_{2} \mathrm{O} 171.99 \mathrm{~g} / 1$ distilled water. The extinction was measured at wavelength $\lambda=620 \mathrm{~nm}$.

The composition of fatty acids was determined by a gas chromatograph (Varian Star 3400CX) with a flame-ionization detector and column DB-23 (30 m long $\times$ $0.5 \mathrm{~mm}$ in diameter), column temperature $100-205^{\circ} \mathrm{C}$, injector temperature $200^{\circ} \mathrm{C}$, detector temperature $240^{\circ} \mathrm{C}$.

\section{Calculations and statistical analysis}

The coefficients of total tract apparent digestibility of dry matter, organic matter, crude fat, $\mathrm{N}$-free extractives and amino acids were calculated by the standard methods. The apparent crude protein digestibility was calculated using the alpha-amino nitrogen $\left(\mathrm{N}-\alpha-\mathrm{NH}_{2}\right)$ method of Pahle et al. (1983) modified by Barteczko et al. (1993). Apparent metabolizable energy corrected to zero nitrogen balance $\left(\mathrm{AME}_{\mathrm{N}}\right)$ was calculated according to Hill and Anderson (1958), using the 
coefficient of $0.0365 \mathrm{MJ}$ per $\mathrm{g}$ of nitrogen retention.

The results were analysed statistically using one-way analysis of variance and Tukey's test (Statistica, 2005). The differences were considered significant at $\mathrm{P}<0.05$.

\section{RESULTS}

The average nutrient content and gross energy of grain did not differ greatly between spring and winter wheat cultivars (Table 1). Crude protein content averaged to $136 \mathrm{~g} / \mathrm{kg}^{-1} \mathrm{DM}$, the lowest values were found for spring cultivar Torka and winter cultivars Mikula and Satyna, and the highest for spring cultivars Vinjett and Napola. The spring cultivar Torka and the winter cvs. Muza and Satyna contained over $700 \mathrm{~g} / \mathrm{kg}$ DM starch and the highest content of amylopectin, whereas Bryza $\mathrm{cv}$. contained only $600 \mathrm{~g}$ starch $/ \mathrm{kg}^{-1} \mathrm{DM}$. The concentrations of crude fibre and fractions of dietary fibre are listed in Table 1.

The amino acid content of wheat grain did not differ greatly between spring and winter wheat cultivars and was lower in cultivars of lower protein content (Table 2). Grain lipids were composed mostly from unsaturated fatty acids, monounsaturated fatty acids (MUFA) averaged about 28\%, whereas PUFA (polyunsaturated fatty acids - linoleic acid C 18:2 ${ }_{n-6}$ and $\alpha$-linolenic acid C 18:2 ${ }_{n-3}$ ) averaged 45\%. The n-6/n-3 PUFA ratio averaged 12 and was lowest in Torka and Bryza cvs. and highest in Muza cv. (Table 3).

The apparent nutrient digestibility and apparent metabolizable energy value of the wheat cultivars are shown in Table 4. Organic matter digestibility averaged $83 \%$, but in Zebra cv. it was only $76 \%$ - from 5 to 10 percentage points lower than in the other cultivars $(\mathrm{P}<0.05)$. Crude protein digestibility averaged $76.4 \%$, but in Zebra cv. it was significantly lower than in Vinjett and Satyna cvs. Crude fat digestibility varied greatly among wheat cultivars and was lowest in Bryza cv. and highest in Napola and Satyna cvs. $(\mathrm{P}<0.05)$. The $\mathrm{AME}_{\mathrm{N}}$ value of the cultivar Zebra was $1.6 \mathrm{MJ} / \mathrm{kg}$ lower than of Muza, and $1.5 \mathrm{MJ} / \mathrm{kg}$ lower than of Napola cv. $(\mathrm{P}<0.05)$, it was accompanied by a $8-9$ percentage points lower energy metabolizability $(\mathrm{P}<0.05)$.

The coefficients of apparent total tract digestibility of lysine were from 7 to 16.5 percentage points lower in winter Muza cv. than in Satyna, Vinjett, Bryza, Napola, Bombona, Mikula and Zebra cvs. $(\mathrm{P}<0.05)$. Similar though smaller differences were found in the digestibility of most other amino acids (Table 5). 


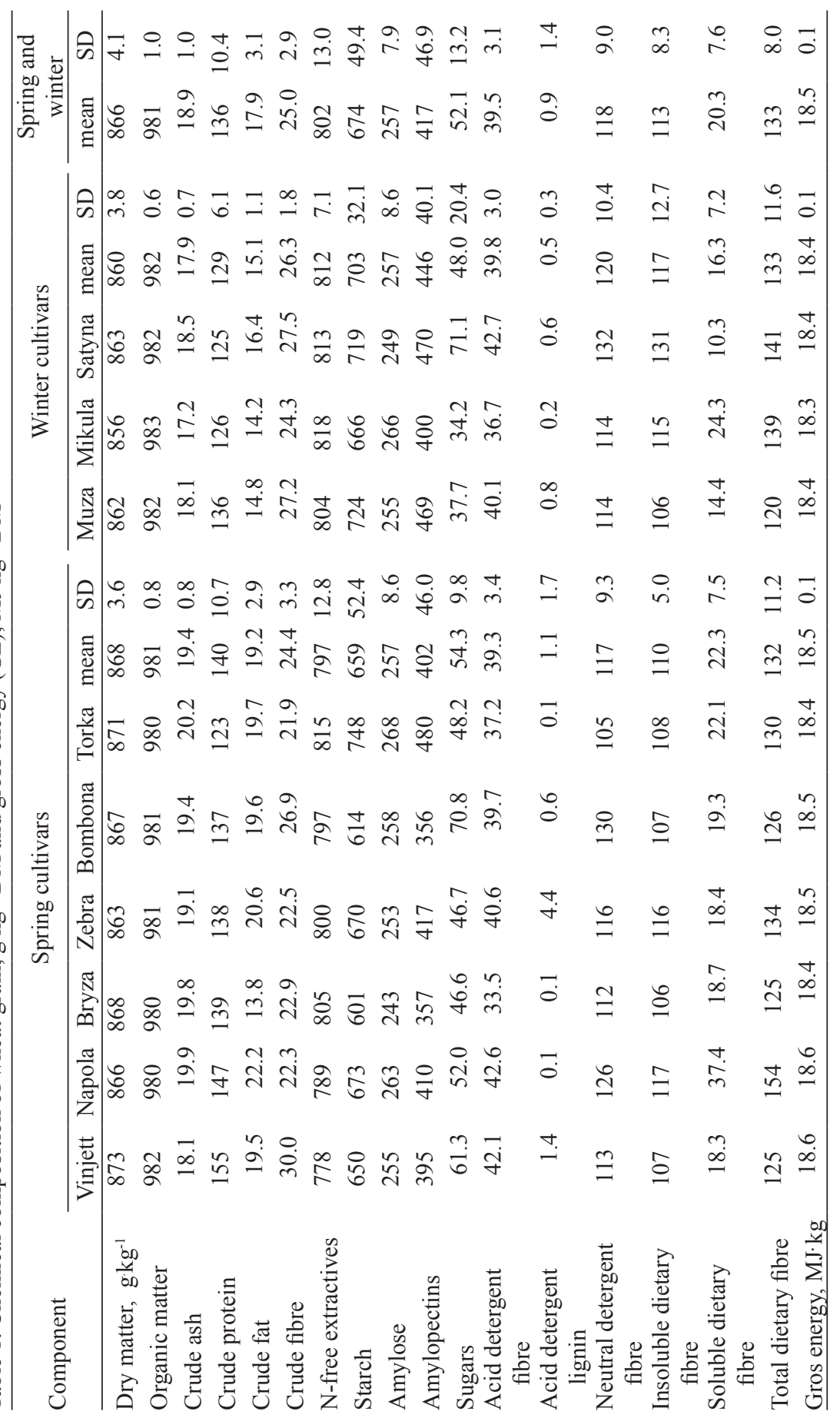




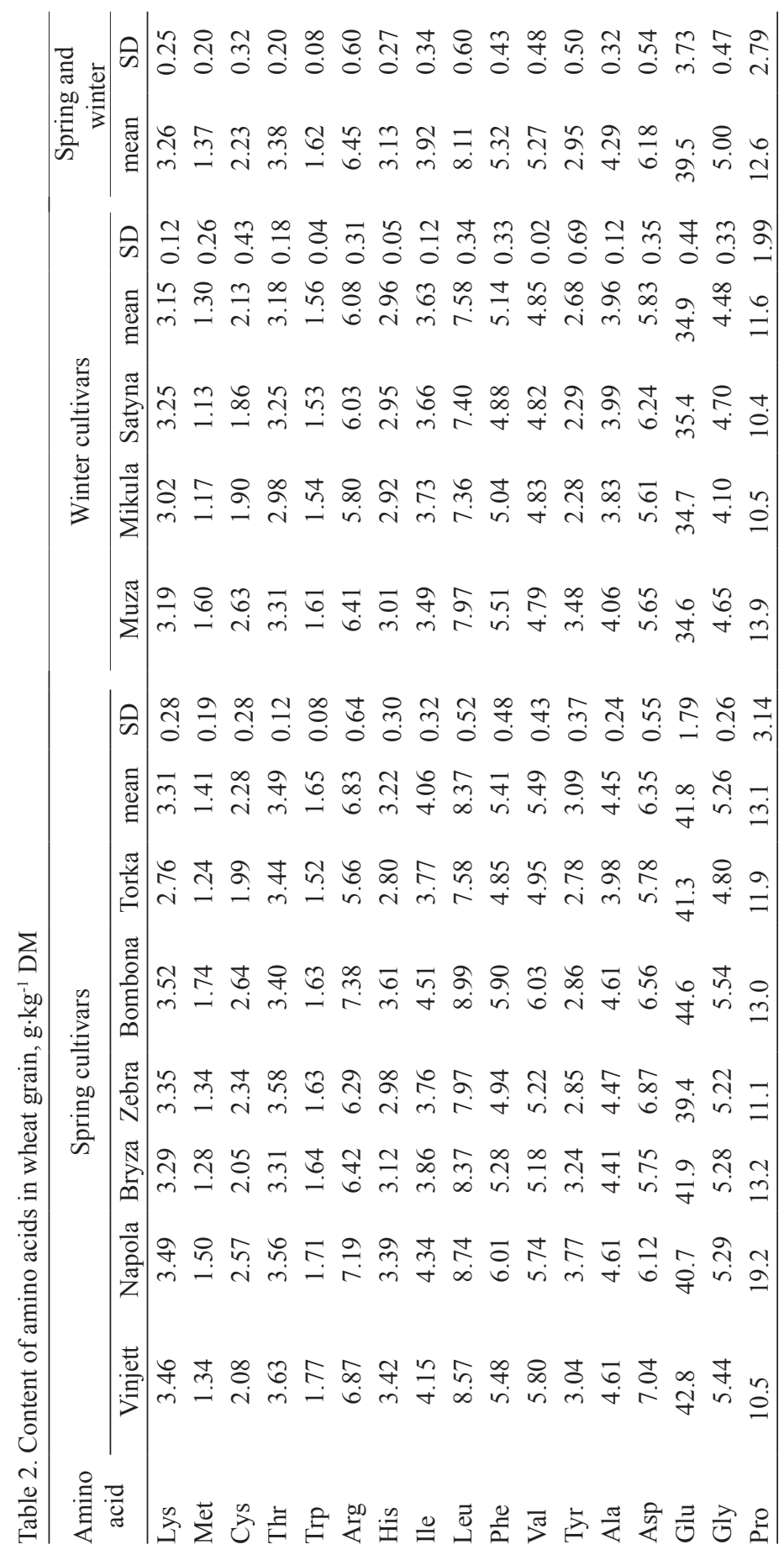




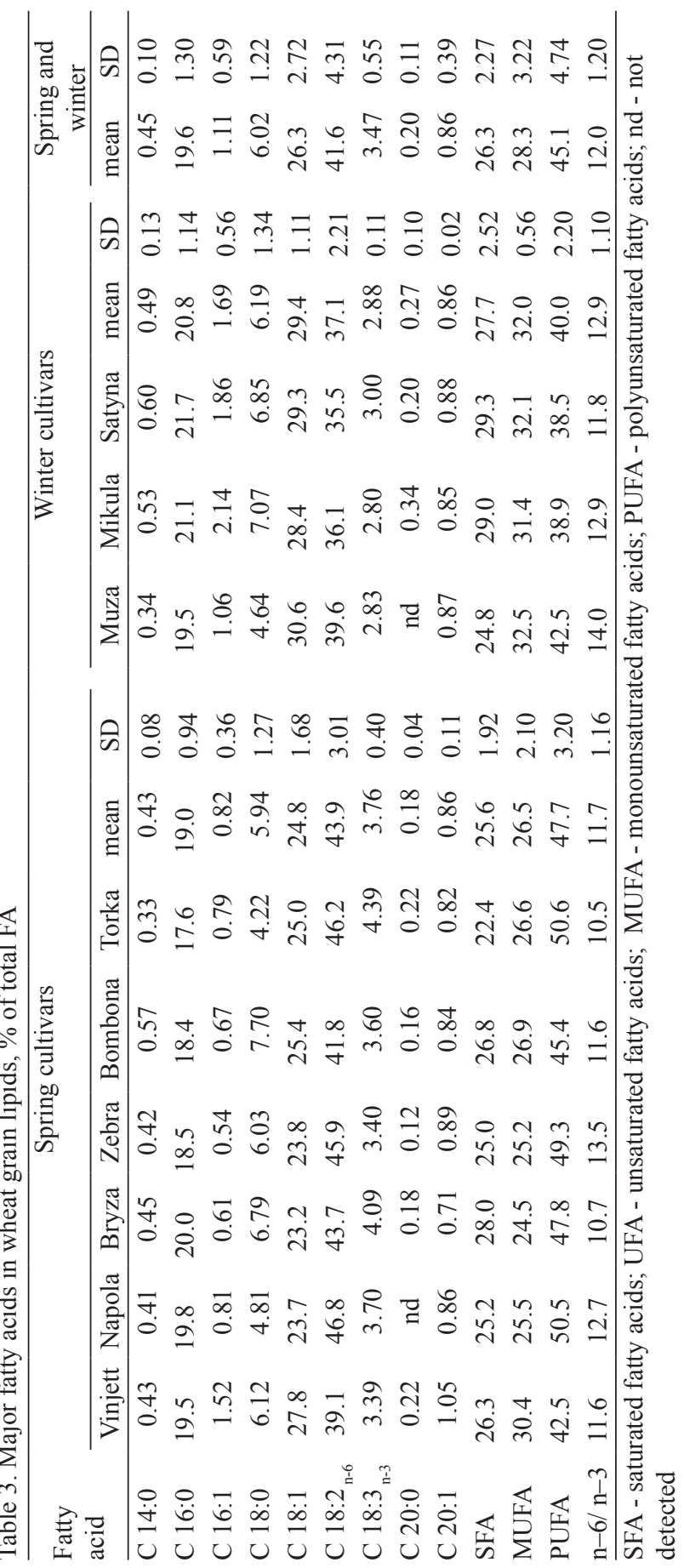




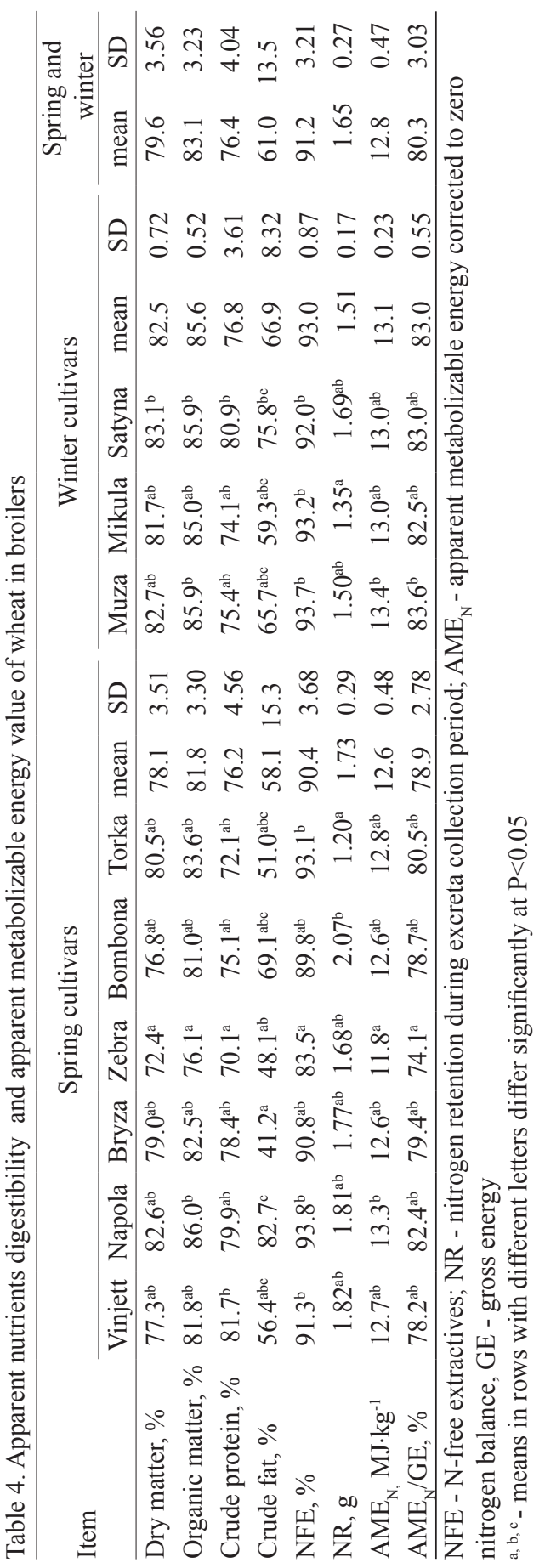




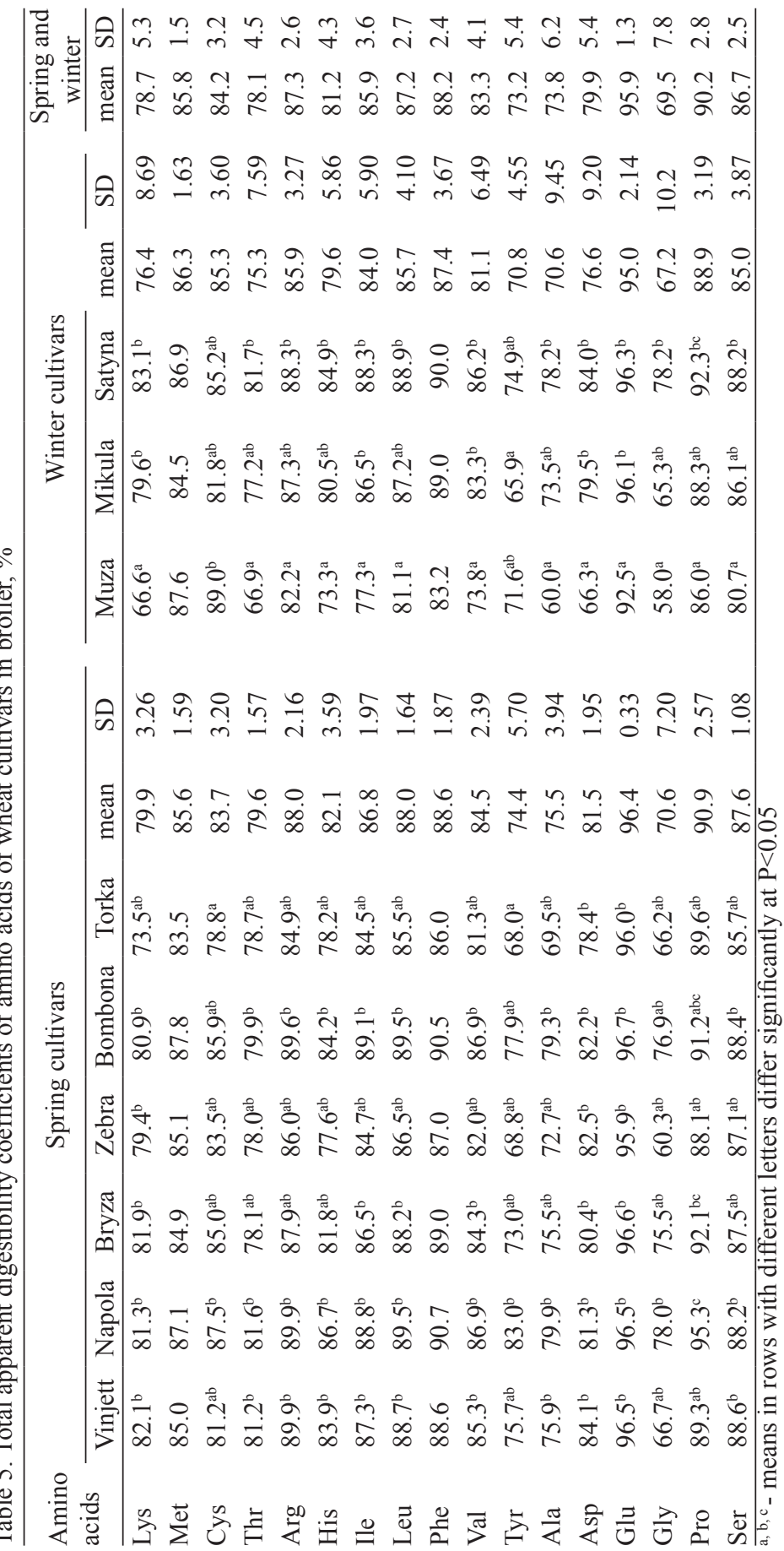




\section{DISCUSSION}

The average crude protein $(\mathrm{CP})$ content of wheat cultivars was similar as shown in Polish (Smulikowska and Rutkowski, 2005) and INRA (Sauvant et al., 2004) tables and varied from 10.7 to $13.5 \%$ on as fed basis. The greater variation, from 7.6 to $15.1 \%$ CP, was reported by Dapoza (2006) in Spanish wheat cultivars and from 9.7 to $19.1 \%$ CP by Kim et al. (2003) in Australian wheat cultivars. Crude protein content of wheat grain is affected by genotype, year of harvest, cultivation site, the level of nitrogen fertilization and the environmental conditions during plant growth, harvest and storage. In our study, the main factor influencing the CP content was the genotype since all cultivars were grown in the same environmental conditions and were harvested in the same year. The crude fat and starch contents of the evaluated wheat cvs. were similar to reported by Sauvant et al. (2004), Smulikowska and Rutkowski (2005) and Gutiérrez-Alamo et al. (2008b). The fatty acids consisted on average of $45 \%$ PUFA, providing about $41.5 \%$ linoleic acid, and 3.5\% $\alpha$-linolenic acid. The ratio of n-6/n-3 PUFA ratio was on average 11.7 in spring cvs. and 12.9 in winter cvs., and was higher than 9.6 shown in INRA tables (Sauvant et al., 2004).

The average starch content of the grain was similar as in cultivars evaluated by Steenfeldt (2001), Svihus and Gullord (2002) and Pirgozliev et al. (2003), but differences between the cultivars were considerable (about 16.5\%). It is well known, that in cereals the apparent metabolizable energy $\left(\mathrm{AME}_{\mathrm{N}}\right)$ for chickens is highly correlated with starch content. In wheat grain, both, the content of starch and amylose to amylopectin ratio depend on the cultivar (Kim et al., 2003) and the energy value of wheat grain in broilers is determined by starch structure and digestion (Gutiérrez-Alamo et al., 2008b). Rogel et al. (1987) showed, that the digestibility of starch in wheat grain may depend not only on the amylose to amylopectin ratio but also on the crystalline structure of the starch molecule and the presence of starch resistant to $\alpha$-amylase in the grain.

In our study, the average digestibility of dry matter, organic matter, crude protein and $\mathrm{N}$-free extractives of different wheat cultivars was similar, whereas the fat digestibility was lower than reported by Carré et al. (2002). Recent studies underline the effect of the content of soluble (SDF) and insoluble (IDF) dietary fibre, non-starch polysaccharides and non-cellulose polysaccharides on the utilization of grain ingredients in broilers (Pirgozliev et al., 2003; GutiérrezAlamo et al., 2008a). The SDF and IDF contents in wheat cultivars evaluated in our study were higher than those reported by Steenfeldt (2001) and Svihus and Gullord (2002) and the IDF and NDF contents were very similar. The fact that it is easy and relatively inexpensive to analyse the content of detergent fibre compared to dietary fibre argues for its determination in poultry and pig feeds 
(Gutiérrez-Alamo et al., 2008b). Compared to the present study, lower ADF content of wheat grain was observed by Kim et al. (2003) and higher content by Gutiérrez-Alamo et al. (2008b). According to Sauvant et al. (2004), wheat contains, on average, about $1 \%$ of ADL. However, in our study a distinctly higher value was obtained for Zebra cv., which was accompanied by the lowest $\mathrm{AME}_{\mathrm{N}}$ value. A significant negative correlation was also found between ADL content and $\mathrm{AME}_{\mathrm{N}}$ value of evaluated wheat cultivars.

It was reported that the $\mathrm{AME}_{\mathrm{N}}$ value may depend on the physical characteristics of the grain soluble fibre, such as viscosity of the water extract (Classen et al., 1995; Carré et al., 2002). The 7 cultivars (Vinjett, Bryza, Zebra, Bombona, Torka, Mikula and Satyna) used in the current study were also used as main components of broiler diets in a previous study (Barteczko et al., 2009). The viscosity of jejunal digesta for the cultivars Bryza and Satyna was higher (4.65 mPas s) than for remaining 5 cultivars including Zebra cv. digesta viscosity, averaged 3.1 mPass (Barteczko et al., 2009). However, in the receent study the $\mathrm{AME}_{\mathrm{N}}$ values of Bryza and Satyna cvs. were comparable to other cultivars, while that of Zebra cv. was $1.5 \mathrm{MJ} / \mathrm{kg}$ lower than that of Napola and Muza cvs. In our study the SDF content has no effect on $\mathrm{AME}_{\mathrm{N}}$ value, similarly as in earlier reports by Annison (1993) and Carré et al. (2002). It can be hypothesized, that the lower $\mathrm{AME}_{\mathrm{N}}$ value of Zebra cv. may be related to a high ADL content. The average $\mathrm{AME}_{\mathrm{N}}$ value of 9 analysed wheat cultivars was $12.8 \mathrm{MJ} / \mathrm{kg}$ and was similar to the values given in Polish tables (Smulikowska and Rutkowski, 2005) and the values shown by Annison (1993) and Carré et al. (2002), but greater by $0.7 \mathrm{MJ} / \mathrm{kg}$ than the average value for wheat shown in INRA tables (Sauvant et al., 2004).

The total tract apparent digestibility coefficients of amino acids obtained in our study were similar to those shown by Smulikowska (1998) but were about $35 \%$ higher than obtained by Rutkowski (1996). It is well known, that the lysine content in wheat is negatively correlated with the protein content, as a proportion of lysine-rich albumins and globulins decreases with an increase of crude protein in grain (Gutiérrez-Alamo et al., 2008a). In our study there was no significant correlation between protein content and lysine content and digestibility. It is likely that differences between cultivars in protein content were too small to cause unfavourable changes in the amino acid composition of protein. The significantly lower digestibility of lysine as well as of most other amino acids was found only in Muza cv., with a protein content close to average.

A comparison of digestibility coefficients of wheat components obtained in the current study with the nutritive value of diets based on the same cultivars of wheat obtained in the previous study (Barteczko et al., 2009) indicates, that the observed differences between cultivars did not significantly affect the performance of broilers. It seems that wheat grain with a protein content not very far from the 
average can be safely included into broiler diets, especially if the viscosity is normalized by the addition of an adequate enzyme preparation.

\section{CONCLUSIONS}

Polish wheat cultivars evaluated in the study differed in the chemical composition to some extent, but the differences did not significantly affect the gross energy as well as fatty acid and amino acid profile. The $\mathrm{AME}_{\mathrm{N}}$ value of evaluated cultivars for broilers averaged $12.8 \mathrm{MJ} / \mathrm{kg}$ on as fed basis.

\section{REFERENCES}

Annison G., 1993. The role of wheat non-starch polysaccharides in broiler nutrition. Aust. J. Agr. Res. 44, 405-422

AOAC, 2005. Association of Official Analytical Chemists, Official Methods of Analysis. $18^{\text {th }}$ Edition. Washington, DC

Barteczko J., Augustyn R., Lasek O., Smulikowska S., 2009.Chemical composition and nutritional value of different wheat cultivars for broiler chickens. J. Anim. Feed Sci. 18, 124-131

Barteczko J., Kamiński J., Marszałek A., 1993. Effect of methods of determination of caecal and urinary nitrogen on the value of apparent protein digestibility coefficient in laying hens of low and high productivity (in Polish). Zesz. Nauk. PTZ, 8, 188-194

Carré B., Idi A., Maisonnier S., Melcion J.P., Oury F.X., Gomez J., Pluchard P., 2002. Relationships between digestibilities of food components and characteristics of wheats (Triticum aestivum) introduced as the only cereal source in a broiler chicken diet. Brit. Poultry Sci. 43, 404-415

Classen H.L., Scott T.A., Irish G.G., Hucl P., Swift M., Bedford M.R., 1995. The relationship of chemical and physical measurements to the apparent metabolizable energy (AME) of wheat when fed to broiler chickens with and without a wheat enzyme source. In: Proceedings of $10^{\text {th }}$ European Symposium on Poultry Nutrition, WPSA. Antalya (Turkey), pp. 169-175

Dapoza C., 2006. How to manage the variability of protein and amino acid contents in raw materials. Amino News ${ }^{\mathrm{TM}}$, Degussa 7 (1), 1-12

Englyst H.N., Cummings J.H., 1988. Improved method for measurement of dietary fibre as nonstarch polysaccharides in plant food. J. Assn. Off. Anal. Chem. 7 (1), 808-814

Faisant N., Planchot V., Kozlowski F., Pacouret M.P., Colonna P., Champ M., 1995. Resistant starch determination adapted to products containing high level of resistant starch. Sci. Aliment. 15, 83-89

Goering H., Van Soest P., 1970. Forage Fibre Analysis. USDA Agriculture Handbook, 379, 1-20

Gutierréz-Alamo A., Pérez de Ayala P., Verstegen M.W.A., Den Hartog L.A., Villamide M.J., 2008a. Variability in wheat: factors affecting its nutritional value. World Poultry Sci. J. 64, 20-39

Gutierréz-Alamo A., Verstegen M.W.A., Den Hartog L.A., Pérez de Ayala P., Villamide M.J., 2008b. Effect of wheat cultivar and enzyme addition to broiler chicken diets on nutrient digestibility, performance, and apparent metabolizable energy content. Poultry Sci. 87, 759-767

Hill F.W., Anderson D.L., 1958. Comparison of metabolizable energy and productive energy determinations with growing chicks. J. Nutr. 64, 587-603 
Kim J.C., Mullan B.P., Simmins P.H., Pluske J.R., 2003. Variation in the chemical composition of wheat grown in Western Australia as influenced by variety, growing region, season and postharvest storage. Aust. J. Agr. Res. 54, 541-550

Morrison W.R., Laignelet B., 1983. An improved colorimetric procedure for determining apparent and total amylose in cereal and other starches. J. Cereal Sci. 1, 9-20

Pahle T., Köhler R., Halle I., Jeroch H., Gebhardt G., 1983. Metodische Untersuchungen zur Bestimmung der Verdaulichkeit des Rohproteins beim Hühnergeflügel. Arch. Tierernähr. (Berlin) 4/5, 367-370

Pirgozliev V.R., Birch C.L., Rose S.P., Kettlewell P.S., Bedford M.R., 2003. Chemical composition and the nutritive quality of different wheat cultivars for broiler chickens. Brit. Poultry Sci. 44, 464-475

Rogel A.M., Annison E.F., Bryden W.L., Balnave D., 1987. The digestion of wheat starch in broiler chickens. Aust. J. Agr. Res. 38, 639-649

Rutkowski A., 1996. Nutritional value of cereals for broiler chickens (in Polish). Ann. Agr. Acad. Poznań. Treatises No. 267

Sauvant D., Perez J.-M., Tran G. (Editors), 2004. Tables of Composition and Nutritional Value of Feed Materials. Pigs, Poultry, Cattle, Sheep, Goats, Rabbits, Horses and Fish. $2^{\text {nd }}$ revised Edition. INRA, Wageningen Academic Publishers

Smulikowska S., 1998. Nutritional value of rye, triticale and wheat in poultry nutrition (in Polish) DSc Thesis. The Kielanowski Institute of Animal Physiology and Nutrition, PAS, Jabłonna (Poland)

Smulikowska S., Rutkowski A. (Editors), 2005. Recommended Allowances and Nutritive Value of Feedstuffs. Poultry Feeding Standards (in Polish). $4^{\text {th }}$ Edition. The Kielanowski Institute of Animal Physiology and Nutrition, PAS, Jabłonna (Poland) and Polish Branch of WPSA

Statistica, 2005. StatSoft, Inc., Version 7.1 www.statsoft.com.

Steenfeldt S., 2001. The dietary effect of different wheat cultivars for broiler chickens. Brit. Poultry Sci. 42, 595-609

Svihus B., Gullord M., 2002. Effect of chemical content and physical characteristics on nutritional value of wheat, barley and oats for poultry. Anim. Feed Sci. Tech. 102, 71-92

Zagrodzki S., Niedzielski Z., Chazo M., 1969. Spectrometric determination of sugars (in Polish). Przem. Spoż. 1, 4 